\title{
The Reconnaissance and Siting of Field Hospitals
}

\author{
A Boreham, MCM Bricknell
}

\begin{abstract}
This paper describes the reconnaissance function for the siting of deployable field hospitals. It reports two levels of reconnaissance, theatre/ operational and tactical. The paper describes the factors to be considered when conducting the reconnaissance and the format of the reconnaissance report.
\end{abstract}

Key words: hospital, design, military.

\section{Introduction}

This paper draws on the previous paper by Bricknell on the Organisation and Design of Field Hospitals published in this Journal (1). That paper referred to both the processes of reconnaissance and siting when discussing field hospital deployment. Field hospitals have been central to the medical support of military operations in the last two decades. This has required the planners at the operational and tactical level to deploy the clinical capability of a field hospital in varying locations, each with its own environmental challenges. These have included the Falklands, Middle East, Africa, Nepal and the Balkans. Locations have ranged from a greenfield or brownfield site, to desert sites and urban sites. This experience, combined with the staff processes encountered during the planning for various exercises since 1999, form the basis of the principles outlined in this paper. The aim of this paper is to describe the reconnaissance function within a field hospital in order to enable members of the AMS to standardize processes at unit level.

\section{Historical Background}

Lieutenant Colonel T B Nicholls RAMC published a book titled the Organization, Strategy and Tactics of the Army Medical Services in War in 1937 (2). Chapter 10 describes the role and function of the Casualty Clearing Station (the precursor of the current Regular field hospital). Many of the principles published in this book were based on lessons learnt from the First World War and are as relevant today as they were in August 1918. 'It should be arranged that hospitals are not sited near dumps, reinforcement dumps, important railway junctions or other military installations. It must be remembered that a large area of ground is required to accommodate both hospital and staff, and to allow for expansion. The area required is: a. For a hospital of 1,200 beds, $800 \times 550$ yards. b. For a hospital of 600 beds, $500 \times 450$ yards.

Large modern schools, or similar institutions, form an admirable site for a casualty clearing station. Unfortunately, this choice of an ideal site may be negated by the danger of shelling and bombing. Under these circumstances it is better to utilize tents and to locate a casualty clearing station at a distance from a town, which has the additional advantage that the ambulance convoys do not experience so much difficulty with traffic congestion.'

The nature of expeditionary operations require field hospital planning staff to be able to conduct a reconnaissance and site their units on ground that they are unlikely to have encountered previously. Field hospitals deployed in the desert during the Gulf War in 1990/91, utilizing tentage in all of the forward locations. They were also deployed to the Balkans during Operations GRAPPLE and RESOLUTE. Here the terrain and environment led to the utilisation of factory infrastructure inconjunction with General Service tentage. On Op AGRICOLA, in Kosovo, a field hospital took over a former prison and installed the clinical function within. Later in the campaign, this hospital was redeployed to a brownfield site in Pristina. On Op CHANTRESS (Angola) and Op SILKMAN (Sierra Leone) Field Hospital Troops deployed to brownfield sites at West African Ports.

A detailed reconnaissance was required for all of these sites in order to create the plan that resulted in the successful establishment of a functioning Role 3 facility. The challenge becomes all the more difficult as the medical services try to achieve peacetime levels of care in austere and challenging environments. Field hospital reconnaissance is normally carried out at two distinct levels: theatre/operational and tactical.

\section{Theatre/Operational Reconnaissance}

At the theatre or operational level it is desirable that Role 3 medical support is considered as part of the earliest military estimate. Ideally an officer from a field hospital should be included in this reconnaissance. Often this is not possible and this responsibility may fall to a single 
medical planner to include the Role 3 (Field Hospital) component within the medical element of the operational level estimate. If the medical planner has no field hospital experience then it is highly desirable that someone with field hospital experience attends a pre-reconnaissance medical planning meeting. At this meeting all the medical stakeholders can provide template information to assist the medical planner. Once engaged on the reconnaissance the medical planner should consider all options for the provision of the Role 3 capability. Much useful information on local medical facilities may be available from medical intelligence sources. If UK forces are likely to deploy a field hospital the medical planner should complete a Pre Deployment Site Survey (PDSS) for each possible site concentrating on Host Nation Support issues. This will provide vital information to allow concurrent planning at the tactical level prior to the deployment of the Field Hospital Reconnaissance Party.

At this level the medical planner's equipment is limited to that which can be carried by an individual. A laptop computer with the ability to connect to the internet is highly desirable. In addition to allowing the draft report to be written whilst on site, commanders can be back-briefed using presentation software. Internet access allows the individual to access a vast library of information and medical intelligence to assist in the medical estimate. A digital camera with a good pixel definition will allow the individual to take photographs, which can be used in the final report and subsequent briefs. Template design solutions should be loaded on the computer in order to act as an aide-memoire.

The main output at this level is to provide sufficient information for the strategic headquarters to be able to include a plan for the Role 3 component in the Medical Directive. This will allow HQ LAND Command, as the Mounting Authority, to conduct its own estimate and issue a Directive to the field hospital(s) required to deploy. This information should also enable the start of the process of generating reinforcements to augment the cadre staff of the field hospital(s). The individuals involved in the reconnaissance should be prepared to attend planning conferences held prior to the deployment of forces.

\section{Tactical Reconnaissance}

The field hospital reconnaissance group is likely to deploy as part of a larger logistic tactical reconnaissance group. The field hospital reconnaissance group should conduct detailed reconnaissance of all the proposed sites, based on the information contained within the Medical Reconnaissance Report and direction from the logistic Commander. This information will allow the hospital commander to conduct the unit level estimate at the tactical level, then issue his desired plan for approval to higher formation. This plan should include a tactical estimate, a detailed pre-deployment site survey (PDSS) and a site template. These documents are vital for the engineers and staff planners in the logistic headquarters to ensure the hospital is provided with the necessary resources (engineer, transport and pioneer support). These documents then become central to the unit level planning.

At the tactical level the field hospital Reconnaissance Group will normally consist of 4 personnel. The principal officer will be the Commanding Officer or the Second in Command. The Regimental Sergeant Major or the Clinical Squadron Sergeant Major will fill the second slot, dependent upon experience in post. The lead planning officer's function is to produce the overall plan and to liaise with outside agencies and higher formations. The second planning officer's role is to have a detailed knowledge of the units' requirements in terms of manpower and infrastructure. The third planning officer slot is filled by a member of support squadron, either the Regimental Quartermaster Sergeant (Maintenance) or (Technical). Their role is to provide the group with the field hospital requirements for the support elements: power, environmental control, supply and catering. The fourth member is normally the Radio/Driver Operator Regimental Signal Instructor, to allow the group to establish the initial unit communications requirement. Extra members of unit personnel, such as unit artisans (electrician, plumber or carpenter) may be included in the reconnaissance group to provide specialist advice.

It would be hoped that by this stage in deployment, an element of the Field Hospital might be in Theatre. Thus, unit equipment will be used to support the field hospital reconnaissance group, including a Land Rover fitted for radio and trailer. This should hold sufficient material, such as accommodation tents, to sustain the reconnaissance party. In addition to this, certain specific equipment is needed. This includes:

(1) Pedometer for confirming the site is sufficient in size to accommodate a field hospital. It will be used to allow the reconnaissance party to mark out ground templates to allow departments to be built quickly once the activation party is on site.

(2) Mine tape or white paint spray for marking out the field hospital template.

(3) Tac signs to mark the location of the field hospital site for the Activation Party, Engineers, Pioneers and Main Body. 
(4) Laptop computer and Digital Camera.

\section{Factors For Siting A Field Hospital}

The medical contribution to the estimate process is covered in some detail in the Medical Supplement to ADP Volume 3 (3). The determination of the Role 3 plan at the Operational level should be based on the conventional '4 D's': demand, distance, destination and duration. This plan should consider the '4C's' (capability, capacity, convenience and continuity) under each of the 4D's. The Operational medical directive will specify the Role 3 requirement by capability (including Theatre level specialisations such as a public health laboratory), capacity and general location. It should be noted that experience from World War II advised that concentration of medical units in the corps area (ie. behind the divisional rear boundary) led to greater efficiency. The advantages were that there was a single destination for casualty evacuation and that minor casualties could be filtered off to the field dressing station and thus reduce the casualty flow to the casualty clearing stations (200 bed field hospitals). The workload at the casualty clearing stations could be managed in rotation, with a period of receiving followed by a period of consolidation and evacuation. This ensured that the clinical staff were not overwhelmed (4).

The tactical estimate for the field hospital is principally concerned with the exact location of the field hospital, the deployment plan and the detailed clinical capability requirements. The field hospital should be located near transport links (including airheads), with good road access. Ideally, mains services (water and electricity) should be available but damage to the local infrastructure may preclude this. The best location for a field hospital is an empty hospital building, but any building with large open spaces may be used to good effect. Experience in World War 1 led to casualty clearing stations (200 bed field hospitals) being sited in tents away from built up areas as these were often targets for artillery fire (5). The Geneva convention only allows the use of the Red Cross to protect medical installations when there is a clear separation of these units from legitimate military targets. The RAMC Training Pamphlet 'Army Medical Services in the Field' published in 1950 (6) advised if the Red Cross flag or ground sign is used it must be placed so that an aircraft can see the sign before arriving over the site ie. it should be placed at the periphery of the site and not only in the centre'. The use of increasingly sophisticated remote surveillance and target acquisition technology in military forces may make the need for the physical segregation of medical units from combatant forces on the battlefield even more important.

\section{Format OfThe Reconnaisance Report}

The written report is the principal planning document that results from the reconnaissance. Whilst similar at both levels, the level of detail changes when it migrates from the operational to the tactical. Although there is no formal format, the estimate provides a useful structure. This has the advantage in that it supports those who will be using the report to formulate their own plans and directives, using the estimate process as the principle tool. The report should include three appendices:

(1) Role 3 Estimate. This document is produced at the operational and tactical level. This allows superior and subordinate headquarters to follow the medical planner's train of thought. The additional information in the tactical assessment of tasks that might be included in the medical estimate for field hospitals is shown in Table 1.

Table 1. The Assessment Of Tasks For The Tactical Medical Estimate for A Field Hospital

1. Hospital C2

a. Command and Ops/Plans

b. Cas reporting and tracking

(1) Clerical sp

(2) AELO

c. Admin Office

d. HQTp

2. Clinical Squadron

a. $\mathrm{A}+\mathrm{E}$

b. Clinical Support
(1) Lab
(2) X-ray
(3) Physio
(4) Dental
(5) Psych
(6) Welfare

c. Surgical Complex

(1) Surgical Teams

i. General

ii. Orthopaedic

iii. Burns

iv. Head and neck

v. Opthalmic

(2) Critical Care

i. ITU (Level 3)

ii. HDU (Level 2)

d. Nursing Services

i. Surgical

ii. Medical

iii. Burns

iv. Specialist

3. Support Squadron
a. Maint $\mathrm{Tp}$
b. MT Tp
c. Med Stores
d. Catering Sect
e. Tech Tp

4. Other - Royal Navy, Joint Capabilities, HNS

5. Theatre Med C2 
(2) Pre-Deployment Site Survey. This document, (an example is at Table 2) is a key document for the Joint Force Logistic Component (JFLogC) planning staff. It considers factors that may require external resources to be identified, staffed and resourced. This document should be passed around the principle desks officers in the JFLogC such as Pioneer Labour Support Unit, Logistic Support, Engineers, Medical and Command and Information Systems. The desk officers should extract the key information to allow then to begin to resource the Role 3 Plan.

(3) Site Template. The site template will allow both JFLogC and unit planners to visualize the field hospital deployment. The most critical information will be the size and dimensions of the site, to allow engineers to resource the correct stores. It can be in the form of a standard template included in the previous paper (1) or digital images of the site may be used.

\section{Summary}

This paper describes the process of reconnaissance during the deployment of a field hospital and its possible redeployment within a theatre of operations. A suggested list of tasks for the tactical estimate for a field hospital is at Table 1 , and an example of a template for a field hospital pre-deployment site survey is shown at Table 2 .

\section{References}

1. Bricknell MCM The Organisation and Design of Regular Field Hospitals. F R Army Med Corps 2001;147:161-167.

2. Nicholls TB. Organisation, strategy and tactics of the Army Medical Services in War. Baillierre, Tindall and Cox. London. 1937.

3. Army Doctrine Publication Volume 3 Logistics Medical Supplement. April 2000.

4. The Army Medical services Campaigns Volume IV North-West Europe HMSO London 1962. pp 285-291.

5. Goodwin WRP.The Casualty Clearing Station as a working unit in the field. $\mathcal{F}$ Roy Army Med Corps 1919:33;42-57.

6. RAMC Training Pamphlet No2 Army Medical Services in the Field. War Office 1950.

Table 2. Pre-deployment Site Survey (PDSS) (factors for 200 bed field hospital on single site)

\begin{tabular}{|c|c|c|c|c|}
\hline $\begin{array}{l}\text { Ser } \\
\text { (a) }\end{array}$ & $\begin{array}{l}\text { Group } \\
\text { (b) }\end{array}$ & $\begin{array}{l}\text { Factor } \\
\text { (c) }\end{array}$ & $\begin{array}{l}\text { Considerations } \\
\text { (d) }\end{array}$ & $\begin{array}{l}\text { Remarks } \\
\text { (e) }\end{array}$ \\
\hline 1 & $\begin{array}{l}\text { MISSION/TASKS } \\
\text { Demand } \\
\text { Capability } \\
\text { Capacity } \\
\text { Convenience } \\
\text { Continuity }\end{array}$ & Size, Type & $\begin{array}{l}\text { Beds } \\
\text { No ST's } \\
\text { All Sp Depts } \\
\text { Expansion/Step Up }\end{array}$ & \\
\hline 3 & Distance & Time & $\begin{array}{l}\text { Time to deploy } \\
\text { Time to opening }\end{array}$ & \\
\hline 4 & Destination & $\begin{array}{l}\text { General Area } \\
\text { Specific }\end{array}$ & $\begin{array}{l}\text { Availability of Sites } \\
\text { Map Packs to be issued }\end{array}$ & \\
\hline 5 & $\begin{array}{l}\text { Threat Tactics, Intent, } \\
\text { Capability }\end{array}$ & $\begin{array}{l}\text { Air, Direct Fire, Indirect Fire, } \\
\text { NBC, Covert, Internal Sy }\end{array}$ & $\begin{array}{l}\text { Protection } \\
\text { Separation fm legit tgts, Flanking } \\
\text { Units, Securable perimeter, COLPRO, } \\
\text { Emergency RV, Alt Loc Defence Stores, } \\
\text { Force Protection Measures in place } \\
\text { with Engrs sp. COLPRO Guard Force }\end{array}$ & \\
\hline 6 & GD/WEATHER & $\begin{array}{l}\text { Terrain, Accessibility } \\
\text { (Gd/Air), Exposure, Climatic Variation, } \\
\text { EH Threats, Environmental Conditions }\end{array}$ & $\begin{array}{l}\text { Clean \& Dry, Hard Standings, } \\
\text { Circuits, Expansion, Heat/Cold, } \\
\text { Air Conditioning Engr Sp } \\
\text { Required } \\
\text { Buildings preferred Floor Space } \\
\text { required: } \\
\text { Hosp } 1000 \mathrm{~m}^{2} \\
\text { RHQ/UAO etc } 50 \mathrm{~m}^{2} \\
\text { QM/Tech/Stores } 100 \mathrm{~m}^{2}\end{array}$ & \\
\hline 7 & $\underline{\text { FF Atts }}$ & $\begin{array}{l}\text { MBLU, SH, Engrs/Pnrs, ASG, } \\
\text { FMED/MPP, Band, AELO }\end{array}$ & $\begin{array}{l}\text { Water/Drainage HLS: (AVTUR), } \\
\text { Sec Access, Parking Refuelling, } \\
\text { Dvr Rest, Med Sup Collection MBLU } \\
\text { or Contract Laundry - MBLU water } \\
\text { requirements - } \\
\text { Laundry } 1450 \mathrm{~L} \text { per hour. } \\
\text { Showers } 4000 \mathrm{~L} \text { per hour. }\end{array}$ & \\
\hline 8 & $\underline{\text { COMMS }}$ & $\begin{array}{l}\text { Tel: SCRA, CNR, } \\
\text { Internal; MATEL use } \\
\text { Internet access } \\
\text { Tele-Medicine }\end{array}$ & $\begin{array}{l}\text { Civil, Sec Comms Check Nets, } \\
\text { Access Land lines } \\
\text { Mobiles } \\
\text { Site Radios } \\
\text { Fax \& OOB UNICOM }\end{array}$ & \\
\hline
\end{tabular}


Table 2. continued

\begin{tabular}{|c|c|c|c|c|}
\hline $\begin{array}{l}\text { Ser } \\
\text { (a) }\end{array}$ & $\begin{array}{l}\text { Group } \\
\text { (b) }\end{array}$ & $\begin{array}{l}\text { Factor } \\
\text { (c) }\end{array}$ & $\begin{array}{l}\text { Considerations } \\
\text { (d) }\end{array}$ & $\begin{array}{l}\text { Remarks } \\
\text { (e) }\end{array}$ \\
\hline 9 & $\underline{\text { UTILITIES }}$ & $\begin{array}{l}\text { Power, Water ( } 42,500 \text { ltrs per day for } \\
\text { hosp use), Drainage, Waste (Clinical, } \\
\text { Domestic, Chemical, Black \& Grey } \\
\text { Water), Mortuary Hardstanding and } \\
\text { Engr Matting }\end{array}$ & $\begin{array}{l}\text { HNS or Unit Power - Mains or } \\
\text { ISO Power Station preferred. } \\
150 \text { ltrs per day per patients (200) } \\
25 \text { ltrs per day per man (500) } \\
\text { Domestic and Clinical Waste Disposal } \\
\text { Portaloos (25) }\end{array}$ & \\
\hline 10 & $\underline{\text { VEHICLES }}$ & $\begin{array}{l}\text { Log Lift into Op Loc. Use of Crane/ } \\
\text { CHRT/RTCH (Loading/Unloading). } \\
\text { Visitors, Circuits, Refuelling and } \\
\text { Parking }\end{array}$ & $\begin{array}{l}\text { HNS or Unit } \\
\text { Parking for } 65 \text { ISOs, } 4 \text { Reeffers, } \\
16 \text { Vehs, Trailers, Generators } \\
\text { POL availability }\end{array}$ & \\
\hline $11 \mathrm{a}$ & $\begin{array}{l}\text { CLINICAL } \\
\text { COMPLEX } \\
\text { Main Group: }\end{array}$ & $\begin{array}{l}\text { A\&E Reception \& Minor Treatment, } \\
\text { Resus } \\
\text { Surgical Pre-Op, OT, CSSD, Post-Op, } \\
\text { ITU, HDU } \\
\text { Clinical Sp: X-Ray, Lab, } \\
\text { Wards - Surgical, Burns H\&N, Medical }\end{array}$ & $\begin{array}{l}\text { Buildings, Tentage, Space, Internal } \\
\text { Circuits } \\
\text { Tentage Plan for Green Field Site. } \\
\text { Tentage requires piped water supply } \\
\text { and drainage }\end{array}$ & \\
\hline $11 b$ & Other Elms: & Wards, Evac, Physio, Dent, Psych, GU & $\begin{array}{l}\text { Buildings, Tentage, Space, Routes, } \\
\text { Cover }\end{array}$ & \\
\hline 12 & $\underline{\text { Sp Sqn }}$ & $\begin{array}{l}\text { Stores: (Unit, POL, HAZMAT, } \\
\text { Wpns/Ammo, Pack Store, Rats, } \\
\text { Med Sup, Stretchers/ Blankets), MT, } \\
\text { LAD, MDSS Wksp }\end{array}$ & Cover or Containers, Space, $100 \mathrm{~m}^{2}$ & \\
\hline 13 & INFRASTRUCTURE & $\begin{array}{l}\text { CP, UAO, Gd Rm, Accn, Messing, } \\
\text { Rest, Trg }\end{array}$ & $\begin{array}{l}\text { Consider Expansion, Power, Lights, } \\
\text { Welfare Equipment } \\
\text { Accn and Catering facilities for staff, } \\
\text { patients and visitors }\end{array}$ & \\
\hline
\end{tabular}

\section{Engineer Support}

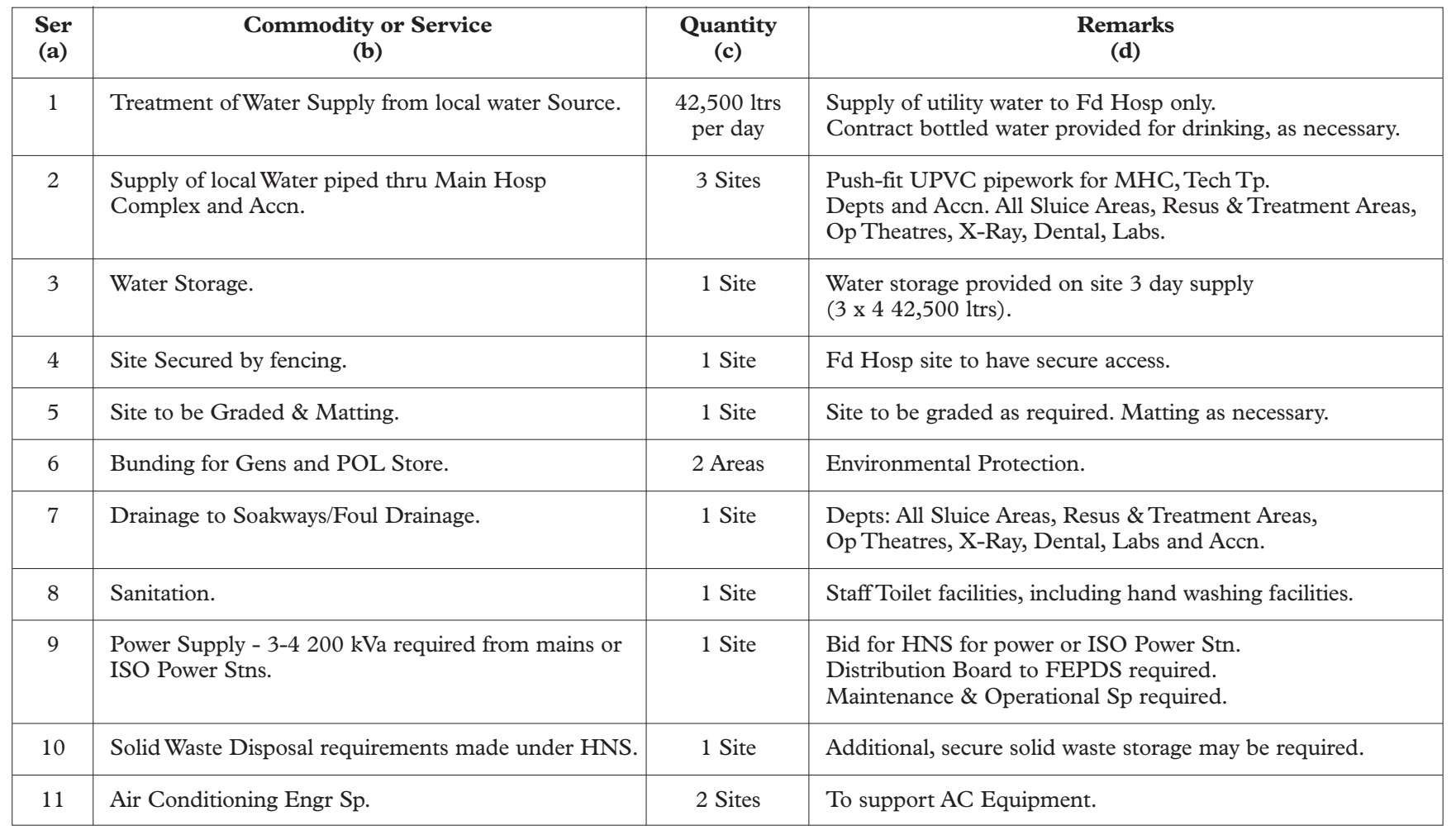


Communication Requirements

\begin{tabular}{|c|c|c|c|}
\hline $\begin{array}{l}\text { Ser } \\
\text { (a) }\end{array}$ & $\begin{array}{c}\text { Commodity or Service } \\
\text { (b) }\end{array}$ & $\begin{array}{l}\text { Quantity } \\
\text { (c) }\end{array}$ & $\begin{array}{l}\text { Remarks } \\
\text { (d) }\end{array}$ \\
\hline 1 & Land Lines. & 4 & Comd and $\mathrm{Sp}$ use. \\
\hline 2 & Fax and OOB UNICOM. & 2 & Land Lines from CP. \\
\hline 3 & Mobile Phones. & 4 & Bid made under HNS. \\
\hline 5 & Access to Internet/Tele-Medicine. & 1 & Land Line or Satellite phone. \\
\hline 6 & Use of CNR Nets \& Ptarmigan. & $\star$ & SCRA access \& $3 \mathrm{C} / \mathrm{S}$ required. \\
\hline
\end{tabular}

\section{Glossary}

$\begin{array}{ll}\text { ST } & \text { Surgical team } \\ \text { Sp } & \text { Support } \\ \text { NBC } & \text { Nuclear, biological chemical } \\ \text { COLPRO } & \text { Collective protection } \\ \text { RV } & \text { rendevous } \\ \text { RHQ } & \text { Regimental headquarters } \\ \text { UAO } & \text { Unit admin office } \\ \text { EH } & \text { Environmental health } \\ \text { MBLU } & \text { Mobile bath and laundry unit } \\ \text { FMED/MPP } & \text { Field Medical Depot/Medical Provisioning Point } \\ \text { AVTUR } & \text { Aviation fuel } \\ \text { SCRA } & \text { Secure radio } \\ \text { CNR } & \text { Combat net radio }\end{array}$

$\begin{array}{ll}\text { MATEL } & \text { Military telephone system } \\ \text { UNICOM } & \text { Personnel data system } \\ \text { CHRT/RTCH } & \text { Container handling equipment } \\ \text { HNS } & \text { Host nation support } \\ \text { POL } & \text { Petrol, oil, lubricants } \\ \text { HAZMAT } & \text { Hazardous material } \\ \text { MT } & \text { Motor transport } \\ \text { LAD } & \text { REME light aid detachment } \\ \text { MDSS } & \text { Medical equipment repair } \\ \text { Gd } & \text { Guard ASG Ambulance support group } \\ \text { FEPDS } & \text { Field electrical power distribution system } \\ \text { C/S } & \text { callsign }\end{array}$

